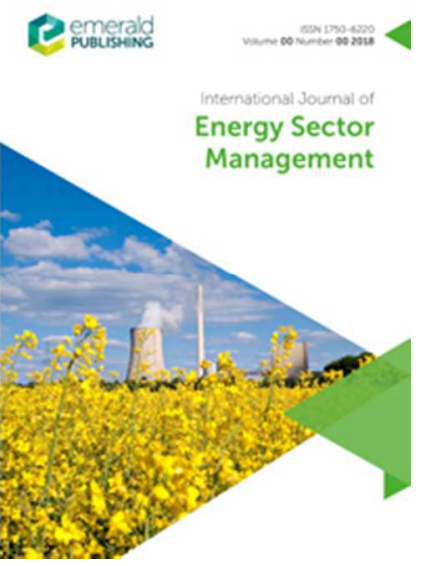

The effect of transitioning to renewable energy consumption on the Nigerian oil and gas exports: An ARDL approach

\begin{tabular}{|c|c|}
\hline Journal: & International Journal of Energy Sector Management \\
\hline Manuscript ID & IJESM-11-2017-0010.R2 \\
\hline Manuscript Type: & Doctorial Thesis Papers \\
\hline Subject Area: & $\begin{array}{l}\text { Renewable energies, Oil and gas exports, Bounds test, Dependency theory, } \\
\text { Energy consumption, Nigeria }\end{array}$ \\
\hline $\begin{array}{r}\text { Methods/ Tools / Analytical } \\
\text { Frameworks: }\end{array}$ & Autoregressive Distributed Lag Model, Time series analysis, ARDL \\
\hline
\end{tabular}




\title{
The effect of transitioning to renewable energy consumption on the Nigerian oil and gas exports: An ARDL approach
}

\begin{abstract}
Purpose: Net Energy Importing Countries (NEICs) pursue strategic policies to reduce the consumption of energy from conventional sources and increase that of renewable energy to attain energy security and sustainable development. However, Net Energy Exporting Countries (NEECs) rely substantially on the proceeds realised from oil and gas exports to mainly NEICs to finance government activities. In this paper, we investigate the effect of increased consumption of renewable energy in developed NEICs on the Nigeria's oil and gas exports.

Design/Methodology: The study was undertaken by analysing macro-economic annual time-series dataset (1980-2014) using Autoregressive Distributed Lag (ARDL) bounds testing approach.

Findings: Both the short-run and the long-run results of the ARDL modelling reveal that renewable energy consumption in developed NEICs is affecting Nigeria's oil and gas exports negatively, thereby causing significant decrease in the amounts of revenue being generated therefrom.

Research limitations: Like most empirical studies, the conduct of this research has encountered some challenges. Thus, the use of rather small sample in terms of period covered (1980-2014), annual frequency of data and focus on one NEEC (Nigeria) are the key limitations of this paper. While the first two challenges were dealt with by using ARDL, future research can focus on other NEECs to extend the study.

Practical implications: Our findings have several policy implications including the need for Nigeria to focus on developing internal market trajectories to increase domestic utilisation of its conventional energy rather than depending on external markets. Our results also suggest the need for public policy makers to develop a strategic plan that will effectively address the external economic threat arising from the influence of global energy transition.

Originality/Value: To the best of our knowledge, this paper represents the first effort to empirically examine the effect of renewable energy consumption by developed NEICs on the Nigeria's oil and gas exports. The paper contributes to the literature by providing insight into, and documenting evidence that the world is taking transitioning to cleaner energy sources very seriously.
\end{abstract}

Keywords: Oil and gas exports; Renewable energy; Consumption; Oil and gas import, Nigeria, ARDL, Bounds test, Dependency theory. 


\section{Introduction}

Energy resources are globally considered significant drivers of socio-economic activities. Generally, energy resources are classified into renewable and nonrenewable. The latter comprises of oil, gas and coal, which are labelled as finite energy resources and their utilisation comes with environmental risks. However, renewable energy is cleaner and derived from such limitless natural resources as wind, water sun or plants. Energies generated from these sources include solar energy, wind energy, biomass energy and hydropower. In much the same way as energy generated from hydrocarbons, these forms of energy could also be used in transportation, electricity generation, heating and cooling. They are abundant, inexhaustible and have less impact on the environment compared to the consumption of energy from oil and gas.

Several countries have adopted various policies, measures and targets to exploit energy from renewable sources to lessen dependence on imported energy sources such as oil and gas (Payne, 2009). The key drivers for transitioning from non-renewable to renewable energy sources are oil price volatility, energy security concerns, economic and environmental sustainability, amongst others (Umbach 2010; Foxon, Hammond and Pearson, 2010; Moriarty and Honnery 2012; Intergovernmental Panel on Climate Change Report, 2014). However, generations of energy from some renewable energy sources have been criticised due to their adverse effects on food crops, land and water quality (Rojagopal and Zilberman, 2007). Also, initial high costs, operational challenges and intermittency problems are associated with renewable energy (Waziri, 2016). Despite the criticisms against the use of renewable energy, numerous studies on the impact of its consumption have been conducted in the literature using different approaches (see, for example, Sari and Soytas, 2004; Szklo and Schaeffer, 2006; Payne, 2009; Menegaki, 2011; Jorgenson, 2012; York, 2012; Smith, 2014). Most of these studies established that utilisation of energy from renewable sources brings about more energy security as well as higher economic and environmental sustainability compared to reliance on non-renewable energy sources. However, similar studies have shown that the global energy transition would have a potential impact on oil and gas exporting countries (Yamin 1998; Akella et al., 2009; York, 2012; Smith, 2014). Yet, other studies argue that the global energy transition regime would not affect net energy exporting countries 
(NEECs) (Barnett et al., 2004; Szklo and Schaeffer, 2006; Johansson, et al., 2009).

In terms of relevant variables, the literature established that energy supply and consumption are measured using macroeconomic and fiscal variables. These include oil price, level of income, level of economic development, population, energy sources, availability of substitutes and technological advancement, amongst others (see, Soytas and Sari, 2003; Wolde-Rufael, 2004; Szklo and Schaeffer, 2006; Akella et al., 2009; Jorgenson, 2012; Tugcu et al., 2012; Von Eije et al., 2012; York, 2012; Smith, 2014). In this study, oil price, GDP per capita and renewable energy consumption in Net Energy Importing Countries (NEICs) were used as key determinants of Nigerian oil and gas exports to NEICs. Of course, some challenges were encountered in measuring these variables, aggregating the key independent variables for the advanced NEICs and determining the frequency of data. We took the natural logarithm of each variable to ensure normality, unify units of measurement and reduce susceptibility to heteroscedasticity. Although there are various methods of aggregation (Saayman and Saayman, 2008; Nosier, 2012), this study opts to use simple summation of each independent variable for the NEICs included in the study except oil price. For the data frequency challenge, we used annual data points, as ARDL has been very efficient in handling yearly data (Shittu et al., 2012).

Nigeria is one of the leading NEECs in Africa and a key member amongst OPEC member countries. Nigeria's oil and gas exports constitute one of the energy sources especially for Europe, USA, and the rest of the world (Nigeria National Petroleum Corporation, 2014). Since Nigeria is a net energy exporter, it is expected that a higher consumption of renewable energy and stringent efforts to run economic activities on substituted energy will reduce developed NEIC's demand for Nigerian oil and gas. Thus, to the best of our knowledge, there is no existing empirical paper on the effect of renewable energy consumption by developed NEICs on the Nigeria's oil and gas exports. This study aims to fill this gap by answering the key research question: how does renewable energy consumption in developed NEICs affect Nigerian oil and gas exports? The remaining sections of the paper are structured as follows. The next section presents dependency theory as the paper's theoretical underpinning and the 
derivation of the research hypothesis of the study. Section 3 explains methodology and data. Section 4 captures the presentation of our results and section 5 discusses them. We finally conclude the paper in section 6 .

\section{Theory and hypothesis}

Dependency theory was originally developed in the 1950 s by researchers in Latin America (Ferraro, 2008) to provide a theoretical underpinning and explanation for the lack of economic development and the dominance of advanced nations in the region and other third world countries. Although, the theory has not enjoyed much support from the western classical economic scholars, still it has been successfully applied to explain developed -developing countries interdependent relationships (see, Ahiakpor, 1985; Agbedi and Virtanen, 2017; Namkoong, 1999; Hoogvelt, 1984; Frank, 1966). For example, Ahiakpor (1985) showed how Ghana failed to benefit economically from its relationship with advanced countries, and suggested a couple of viable economic policies for Ghana based on the principles of dependency theory. In a recent study, Agbedi and Virtanen (2017) attempted to use the lens of dependency theory to explain the interdependent relationship between African countries and China and concluded that the theory is suitable and useful in explaining some aspects of the relationship. Nevertheless, the authors (Agbedi and Virtanen, 2017) contend that other economic theories need to be applied to explain the complexities of such relationship. Similarly, Balcilar et al. (2017) tested and established the existence of dependency theory in trade relationships between Greece and Turkey as patrons, on one hand, and Republic of Cyprus and Turkish Republic of Northern Cyprus as peripheries, on the other.

Consequently, this study is also underpinned by dependency theory propounded by Sunkel, (1969), Dos Santos (1970) and Frank (1972). Firstly, the theory postulates the existence of international system comprising two distinct resource dependent and consumer countries that are engaged in an economic interdependent relationship. Secondly, the theory assumes that the dominant resource consumers exercise great influence within the economies of the resource dependent countries. Thirdly, the theory predicts the existence of dynamic relations between the two distinct countries. A fourth aspect of the theory which makes it more appealing to our study is its interest in the 4 
interdependent relation between a mono-product third-world country which depends heavily on export revenues from its mono product mainly sold to advanced and more diversified economies (Ferraro, 2008). Building on this theory, we contextualise these two groups of countries as net energy exporting countries (NEECs) - for example Venezuela, Saudi Arabia, Iran and Nigeria - and net energy importing countries (NEICs) - example, Germany, United Kingdom, Italy and France. In reality, most oil and gas NEICs are the economically advanced countries of the west while NEECs are mainly developing economies located in North America, Asia and Africa. This study argues that Nigeria as a NEEC engages in global oil and gas export trade with different NEICs. Due to Nigeria's weak financial and technical expertise in the petroleum sector, it relies on external financing for the extraction of its oil and gas resources for exports to the homes of NEICs (Agbaeze et al., 2015; Aliyu, 2005; Yergin, 2006; 2008; Waziri, 2016). In this relationship, NEICs exercise significant influence within the economy of Nigeria because of the country's abundant mineral resources (Santos, 1971; Sunkel, 1969; Waziri, 2016) and its vulnerable and exploitable nature as a less developed country (Belal et al., 2013; Hassan and Kouhy, 2014). In addition, the economic relationship between Nigeria and the NEICs has been dynamic over the years. This dynamism is evident in the hydrocarbon trade relationship between Nigeria and USA. Thus, before the discovery and the earnest commencement of shale oil and gas exploitation, USA had been a major destination for Nigeria's oil and gas exports, accounting for about $43 \%$ of its total export volume (Nigerian National Petroleum Corporation, 2015). While oil and gas exports to USA have shown a dramatic decrease to about 4\%, exports to Europe have increased tremendously to nearly $46 \%$ (Nigerian National Petroleum Corporation, 2015). This development has made Europe the leading oil and gas exports destination for Nigeria. However, this ranking of Europe as Nigeria's major oil and gas exports destination may change in the foreseeable future, as the continent has made huge investments in renewable energy systems as a result of which there are several technological innovations that are about to come on stream.

Since renewable energy is considered an alternative to conventional energy, substituting conventional energy consumption with renewable energy in NEICs may have the potential of deéreasing global oil and gas consumption and prices. 
This may affect the volume of Nigeria's oil and gas exports to NEICs thereby affecting oil and gas exports revenue and budget financing. Consistent with dependency theory, this paper argues that hydrocarbon exports from Nigeria, as a NEEC, may be adversely affected. The possible decline in Nigeria's exports of oil and gas might be strongly linked to the advanced NEICs' commitments to lessen the consumption of oil and gas to attain energy security and minimise the influence of oil price shocks. Consequently, we hypothesise that:

renewable energy consumption in developed NEICs will have significant negative influence on Nigeria's oil and gas exports.

\section{Methodology}

\subsection{Data}

To test the hypothesis developed in section 2, the study has collected macroeconomic secondary data from different sources, including national and international data banks. The data collected for all variables are in the form of annual time-series for the period 1980 to 2014. The main dependent variable is the Nigeria's oil and gas exports to the developed NEICs (I4 selected EU member countries and USA). On the other hand, the independent variables include renewable energy consumption, GDP per capita of the selected developed NEICs and oil price. All the variables used in this study were transformed to natural logarithmic forms to normalise the distribution of the data and unify the different units of measurements thereby simplifying interpretations of results.

In relation to data aggregation, there exist numerous methods in the literature (Lin and Sung, 1983; White, 1985; and Saayman and Saayman, 2008). However, Nosier (2012) opines that there is no general method of aggregation available in the literature, as each study can adopt any method that suits its circumstance. This study aggregated the annual data for each of the independent variables in the model, except oil price. Thus, the annual data for renewable energy for the fifteen developed NEICs were aggregated to arrive at the total for each year. This was repeated for all the remaining independent variables. The aggregated totals, which had been reached through the previous steps, were then tabled for each of the independent variables and combined with the dependent variable to run the model. Table 1 below presents the variables' acronyms, descriptions and sources. 
Table 1 Variables and data sources

\begin{tabular}{llll}
\hline Variables & Description & Units of measurements & Sources \\
\hline NOE & $\begin{array}{l}\text { Nigerian oil and gas } \\
\text { exports to developed } \\
\text { NEICs }\end{array}$ & $\begin{array}{l}\text { Barrels of oil equivalent } \\
(\mathrm{BOE})\end{array}$ & $\begin{array}{l}\text { International Energy } \\
\text { Agency (IEA) and } \\
\text { Nigerian National } \\
\text { Petroleum Corporation } \\
\text { (NNPC) }\end{array}$ \\
REDE & $\begin{array}{l}\text { Renewable energy } \\
\text { consumption in developed } \\
\text { NEICs }\end{array}$ & Billion kilowatt/hrs & EIA \\
GDPDE & $\begin{array}{l}\text { GDP per capita in } \\
\text { developed NEICs }\end{array}$ & Constant US Dollars & World Bank \\
OPD & Oil price in US Dollars & US Dollars & $\begin{array}{l}\text { Central Bank of Nigeria } \\
\text { (CBN) }\end{array}$ \\
\hline
\end{tabular}

\subsection{Model specifications - The ARDL}

ARDL is a versatile time-series regression model introduced by Pesaran and Shin (1998) and Pesaran et al. (2001), which is doing very well in addressing some of the short-comings of the more traditional cointegration techniques. These shortcomings include strict requirements for all variables to be $I(1)$, less efficiency with inclusion of dummy variables (Ahmad and Du, 2017; Marques et al., 2016; Pesaran et al., 2001) and the strict condition of large sample asymptotic. In this regard, Pesaran et al. (2001) mentioned the first merit of the technique, demonstrating that with small sample, ARDL performs better than Johansen cointegration. Narayan (2004) draws our attention to two additional advantages of ARDL as follows. First, as a cointegration technique, ARDL avoids endogeneity and serial correlation problems. Second, variables for inclusion in the modelling do not have to be nonstationary in level. Furthermore, Marques et al. (2016) points out a fourth advantage, noting that unlike traditional cointegration techniques, the inclusion of dummy variables does not vitiate the efficiency of the model. Therefore, in view to these advantages, the number of studies employing ARDL in estimating relationships amongst various time-series variables of interest has skyrocketed significantly over the last 17 years (example, Tursoy and Faisal, 2017; Sun et al., 2017; Rahman and Kashem, 2017; Marques et al., 2016; Narayan, 2002, 2014; Murthy and Okunade, 2016; Odhiambo, 2009; Fuinhas and Marques, 2012; Ozturk and Acaravci, 2010, 2011, to mention just very few). 
Therefore, consistent with bounds testing technique used by many studied as cited above, we estimated ARDL model to ascertain the relationship between the dependent and the independent variables identified in this study. However, it is pertinent to clarify that there are other methods ${ }^{1}$ of executing cointegration test which mostly require large samples and the integration of all variables in the order I(1). As discussed above, ARDL technique is believed to have several advantages over other conventional methodologies. Its adaptability means that it can be applied irrespective of whether the basic regressors are absolutely $I(0)$, $I(1)$, or mutually cointegrated. Although, ARDL can be used to model relationships amongst endogenous and exogenous variables as long as none of them is integrated of order two, I(2), Tursoy and Faisal (2017) caution that the dependent variables must be $I(1)$. Secondly, the methodology can be applied to studies that utilise small sample-sized dataset. ARDL is particularly attractive to our study, because the 35-year annual time-series (1980-2014) for our paper may be described as rather small sample and the dependent variable is cointegrated in the order $I(1)$.

\subsection{Estimation technique and procedure}

ARDL time-series analysis is characterised by a basic procedure that is expected to be followed in its application. The first step in conducting ARDL is to investigate the unit properties of the relevant variables via unit root tests to ascertain their stationarity. Consequently, the bounds testing approach is employed using the Fisher's F-statistics to examine the long-run cointegrating relationship between the dependent and the independent variables. The general form of the model is given as follows.

Given that:

$N O E=f(R E D E, D P D E, O P D)$

An OLS time-series can be modelled in log-level form as follows:

$$
\ln N O E_{t}=\alpha_{0}+\lambda_{1} \ln (R E D E)_{t}+\lambda_{2} \ln (G D P D E)_{t}+\lambda_{3} \ln (O P D)_{t}+\mu_{t}
$$

\footnotetext{
1 There are other methods used in conducting cointegration test. The most popular ones are Johansen (1991) maximum likelihood approach and the Phillips and Hansen (1990, PH) fully modified OLS procedure. Other methods also being used include the two-step method of Engle and Granger (1987) and the leads and lags estimation procedure proposed by Saikkonnen (1991).
} 
Where InNOE is the dependent variable measured as the natural log of Nigerian oil and gas exports demand by the selected developed NEICs. InGDPDE stands for the natural log of GDP per capita in developed NEICs. InOPD is the natural log of oil price. However, InREDE represents renewable energy consumption in developed NEICs, and $\mu_{t}$ is the disturbance term. Lastly, $\lambda_{1}, \lambda_{2}, \lambda_{3}$ are the coefficient elasticities of the independent variables and $\alpha$ stands for constant. Following Narayan (2002) approach, the ARDL model of this study is restated as follows:

$$
\begin{aligned}
\Delta \ln (N O E)_{t}= & \alpha_{0}+\lambda_{1} \ln (N O E)_{t-1}+\lambda_{2} \ln (R E D E)_{t-1}+\lambda_{3} \ln (G D P D E)_{t-1}+\lambda_{4} \ln (O P D)_{t-1} \\
& +\sum_{i=1}^{p} \gamma_{1} \Delta \ln (N O E)_{t-i}+\sum_{i=0}^{q} \gamma_{2} \Delta \ln (R E D E)_{t-i}+\sum_{i=0}^{r} \gamma_{3} \Delta \ln (G D P D E)_{t-i} \\
& +\sum_{i=0}^{S} \gamma_{4} \Delta \ln (O P D)_{t-i}+\vartheta_{t}
\end{aligned}
$$

Model (3) is the unrestricted ARDL model specified as conditional error correction model with $\lambda_{1} \ln (N O E)_{t-1}+\lambda_{2} \ln (R E D E)_{t-1}+\lambda_{3} \ln (G D P D E)_{t-1}+\lambda_{4} \ln (O P D)_{t-1}$ replacing the error correction term $\left(\varphi E C T_{t-1}\right)$ of a standard error correction model. However, $p, q, r$ and $s$ are the optimal lag lengths and the remaining parameters have been explained in equation (2). All the variables are in natural logarithm form as indicated by the natural log operator, In. An F-test was conducted to ascertain whether the variables are cointegrated; that is if they have long-run relationship. The null hypothesis for the bounds test is stated as $H_{0}: \lambda_{1}=\lambda_{2}=\lambda_{3}=$ $\lambda_{4}=0$, tested against the alternative hypotheses $H_{1}: \lambda_{1} \neq \lambda_{2} \neq \lambda_{3} \neq \lambda_{4} \neq 0$.

Similarly, the computed F-statistic is assessed using the critical values introduced by Pesaran et al. (2001). These critical values are of two types, namely the lower bound critical values and the upper bound values. The former expects all the variables to be $I(0)$ while the latter assumes all variables to be $I(1)$. The decision rule is as thus: if the calculated F-statistic is less than the lower bound value, then $\mathrm{H}_{0}$ cannot be rejected. Conversely, when the calculated F-statistic is greater than the upper bound value, then we reject $\mathrm{H}_{0}$ and conclude that there is a long-run relationship between the variables of this study. However, when the calculated value lies amid the two extreme limits, then our outcome is considered inconclusive. When the bounds test result is inconclusive, 
Tursoy and Faisal (2017) remind us to rely on the error correction term in deciding whether there is a long-run relationship among the variables of interest. Thus, if the coefficient of the error correction term, as shown in the short-run error correction model, is negative and statistically significant, we conclude that long-run relation does exist (Kremers et al., 1992; Bernerjee et al., 1998). This informs the need to estimate a long-run equation, which is essentially a level OLS model, specified as follows:

$$
\operatorname{In}(N O E)_{t}=\beta_{0}+\beta_{1} \ln (R E D E)_{t}+\beta_{2} \ln (G D P)_{t}+\beta_{3} \ln (O P D)_{t}+v_{t}
$$

In order to estimate the short-run coefficients, a dynamic error correction model (ECM) will be estimated. The ARDL specification of the ECM is presented as follows:

$$
\begin{aligned}
& \Delta \ln (N O E)_{t}= \gamma_{0} \\
&+\sum_{i=1}^{p} \gamma_{1} \Delta \ln (N O E)_{t-i}+\sum_{i=0}^{q} \gamma_{2} \Delta \ln (R E D E)_{t-i}+\sum_{i=0}^{r} \gamma_{3} \Delta \ln (G D P D E)_{t-i} \\
&+\sum_{i=0}^{s} \gamma_{4} \Delta \ln (O P D)_{t-i}+\varphi E C T_{t-1}+\eta_{t}
\end{aligned}
$$

Where $\varphi$ is the coefficient of the error correction term indicating the speed at which the variables meet at equilibrium position. At this point, it is important to consider the selection of optimal lag length at all the phases of analysis specified above. Usually, two main lag length selection criteria are utilised. These are the Schwarz Bayesian Criterion (SBC) and Akaike Information Criterion (AIC). The SBC performs a repetitive search to select a parsimonious model. This means it selects the minimum likely lag length. In contrast, the AIC selects the maximum lag length. However, the SBC-based model is considered to have minor forecast error than the AIC (Jalil and Ma, 2008). Thus, the SBC-based model is preferred in this paper over the AIC-based lag length selection criterion.

Moreover, various diagnostic tests were deployed to ensure the goodness of fit of our models and consistency of the results for policy formulation and recommendations. Thus, serial correlation test, normality test, stability test and heteroskedasticity test were conducted. Similarly, as suggested by Pesaran and Pesaran (2010), the cumulative sum of recursive residuals (CUSUM) and the cumulative sum square of recursive residuals (CUSUMSQ) tests were carried out to verify structural stability. 


\section{Empirical results}

We commence this section by, first, presenting such descriptive statistics as mean, median, maximum, minimum and standard deviation. Thus, the purpose of presenting Table 2 is to highlight the properties of our time-series dataset.

Table 2 Summary of descriptive statistics for the dataset

\begin{tabular}{lllllll}
\hline Variables & Mean & Median & Maximum & Minimum & Std. Dev. & Obs. \\
\hline $\ln (N O E)_{t}$ & 8.65 & 8.671 & 8.782 & 8.512 & 0.074 & 35 \\
$\ln (O P D)_{t}$ & 1.33 & 1.342 & 2.201 & -0.259 & 0.873 & 35 \\
$\ln (R E D E)_{t}$ & 2.94 & 2.938 & 3.183 & 2.811 & 0.099 & 35 \\
$\ln (G D P D E)_{t}$ & 5.66 & 5.667 & 5.763 & 5.509 & 0.087 & 35 \\
\hline
\end{tabular}

First, we look at the mean and median both of which measure central tendency. The mean measures the average value a variable possesses over the period while the median indicates the position of the middle observation in the distribution. Both the mean and the median appear to show very similar values, somewhat implying that the distribution is likely symmetrical. However, when they are not, the distribution may be considered skewed and non-normal. Secondly, the standard deviation gives the deviation of the actual values from the mean value. The differences between the actual values from the mean values for the variables suggest variability of Nigerian oil and gas exports to developed NEICs and other related independent variables. The fact that standard deviations are less than the means for all variables is an indication that we do not need to worry about outliers. Thirdly, the difference between the maximum and minimum values represents the range, which appears to lie within the positive region for all the variables, except oil price. Overall, the data is consistent, as both the mean and median are within the scope of the maximum and minimum values and the standard deviation is less than the mean and the median for all variables thereby ruling out any severe case of outliers.

\subsection{Unit root tests}

To avoid spurious results and invalid inferences, the study conducted Augmented Dickey-Fuller (ADF) and Philips Perron (PP) unit root tests. These tests were conducted using different specifications (with constant, and with constant and trend) to ascertain the level of integration of the variables and to satisfy the 
ARDL-bounds testing requirements. First, we conducted the unit root tests at levels and the results are presented in Table 3.

Table 3 ADF and PP tests results on log-level variables

\begin{tabular}{l|c|c|c|c|c}
\hline \multirow{2}{*}{ Variables } & \multicolumn{2}{|c|}{ ADF Statistic } & \multicolumn{2}{c|}{ PP Statistic } & \multirow{2}{*}{ Stationary Status } \\
\cline { 2 - 5 } & Constant & $\begin{array}{l}\text { Constant } \& \\
\text { Trend }\end{array}$ & Constant & $\begin{array}{l}\text { Constant \& } \\
\text { Trend }\end{array}$ & Non-stationary \\
\hline $\ln (N O E)_{t}$ & -2.24 & -0.66 & -2.47 & -1.96 & Non-stationary \\
$\ln (O P D)_{t}$ & 2.45 & -0.5 & 6.07 & 0.3 & Non-stationary \\
$\ln (R E D E)_{t}$ & -1.86 & -0.78 & -1.87 & -0.84 & Non-stationary \\
$\ln (G D P D E)_{t}$ & -1.92 & -0.64 & -1.85 & 0.15 & \\
\hline
\end{tabular}

Notes: $* * *, * *$ and $*$ denote statistical significant, i.e. rejection of the null hypothesis, at $1 \%, 5 \%$ and $10 \%$ levels of significance respectively.

The results obtained from both $\mathrm{ADF}$ and PP unit root tests indicate that all the variables have unit root and are therefore non-stationary. Thus, the need for another round of unit root tests at first difference. Consequently, based on the second round results, all variables in the dataset became stationary at first difference, as presented in Table 4.

Table 4 ADF and PP test results on first-differenced log-level variables

\begin{tabular}{l|l|l|l|l|c}
\hline \multirow{2}{*}{ Variables } & \multicolumn{2}{|c|}{ ADF Statistic } & \multicolumn{2}{c|}{ PP Statistic } & \multirow{2}{*}{$\begin{array}{c}\text { Stationary } \\
\text { Status }\end{array}$} \\
\cline { 2 - 5 } & Constant & $\begin{array}{l}\text { Constant \& } \\
\text { Trend }\end{array}$ & Constant & $\begin{array}{l}\text { Constant \& } \\
\text { Trend }\end{array}$ & $I(1)$ \\
\hline $\ln (N O E)_{t}$ & $-7.41 * * *$ & $-7.54 * *$ & $-7.42 * * *$ & $-7.57 * * *$ & $I(1)$ \\
$\ln (O P D)_{t}$ & $-6.08 * * *$ & $-7.13 * *$ & $-6.09 * * *$ & $-8.04 * * *$ & $I(1)$ \\
$\ln (R E D E)_{t}$ & $-4.94 * * *$ & $-5.35 * * *$ & $-4.94 * * *$ & $-5.65 * * *$ & $I(1)$ \\
$\ln (G D P D E)_{t}$ & $-3.19 * *$ & $-3.74 * *$ & $-3.18 * *$ & $-3.54 * *$ & \\
\hline
\end{tabular}

Notes: $* * *, * *$ and $*$ denote statistical significant, i.e. rejection of the null hypothesis at $1 \%, 5 \%$ and $10 \%$ levels of significance respectively.

Therefore, the null hypotheses, which state that the variables are not stationary, are rejected and this confirms that the variables are stationary at first difference implying that all variables are $I(1)$. This further suggests that the statistical properties of the data such as the mean, variance and auto-correlations are constant overtime and the model possesses the power to make accurate predictions. As such, we conclude that for all variables unit root can be eliminated at first difference and the data can be used for ARDL econometric modelling. After the unit root tests, the second step focuses on the conduct of bounds test to determine whether the dependent and independent variables are 
cointegrated (Pesaran et al., 2001). However, to facilitate the estimation of the bounds test results, the base-line ARDL model is estimated and parented in Table 5.

Table 5 Base line ARDL model

\begin{tabular}{lrr}
\hline Dependent variable is $\Delta \ln (N O E)$ & Coefficient & Probability \\
Regressor & $-1.042^{* * *}$ & 0.0003 \\
\hline $\ln (N O E)(-)$ & $-1.972 * * *$ & 0.0000 \\
$\ln (R E D E)(-)$ & $-1.137 * *$ & 0.0124 \\
$\ln (G D P D E)$ & 0.053 & 0.2346 \\
$\ln (O P D)$ & $0.359^{* *}$ & 0.0160 \\
$\Delta \ln (N O E)(-)$ & $-1.894^{*}$ & 0.0650 \\
$\Delta \ln (G D P D E)$ & 0.011 & 0.8910 \\
$\Delta \ln (O P D)$ & $-0.256^{* *}$ & 0.0180 \\
$\Delta \ln (R E D E)$ & $-1.555^{* *}$ & 0.0260 \\
$\Delta \ln (R E D E)(-)$ & 18.92014 & 0.0148 \\
$C$ & & $67 \%$ \\
\hline R-Squared & & $65 \%$ \\
Adjusted R-Squared & & 2.1956 \\
Durbin-Watson statistic & & 33 \\
Observation (1983-2014) & & $(1,0,0.1)$ \\
\hline
\end{tabular}

The table reports the unrestricted and conditional error correction ARDL $(1,0,0,1)$ estimates. Lag length for each variable was automatically selected by Eviews based on Schwarz Bayesian Criterion. $* * *, * *$ and $*$ denote statistical significant, i.e. rejection of the null hypothesis, at $1 \%, 5 \%$ and $10 \%$ levels of significance respectively.

The bounds test was conducted to establish the existence of long-run relationship between the dependent and independent variables of the study testing $\mathrm{H}_{0}: \lambda_{1} \lambda_{2}=\lambda_{3}=\lambda_{4}=0$ (no long-run relationship) for the base line ARDL model (model 3) against the alternative $\mathrm{H}_{1}: \lambda_{1} \neq \lambda_{2} \neq \lambda_{3} \neq \lambda_{4} \neq 0$. Table 6 presents the results of the F-test along with associated critical values.

Table 6 Bounds tests (F-test)

\begin{tabular}{llcr}
\hline Test Statistic & Value & Df & Probability \\
\hline F-statistic & $\mathbf{5 . 3 5 *}$ & $(4,20)$ & 0.0043 \\
Chi-square & $21.39 *$ & 4 & 0.0003 \\
\hline \multicolumn{4}{c}{ Critical values } \\
\hline Level of significance & $\mathrm{I}(0)$ & $\mathrm{I}(1)$ & \\
\hline $1 \%$ & 4.522 & 5.792 & \\
$5 \%$ & 3.16 & $\mathbf{4 . 1 9 4 *}$ & \\
$10 \%$ & 2.626 & 3.55 & \\
\hline
\end{tabular}


The results of the bounds test presented in Table 6 show that the F-static (5.348) is greater than both the upper and lower critical bounds at $5 \%$ level of significance. Therefore, the null hypothesis of no long-run relationship is rejected and we conclude that there is cointegrating relationship between the variables in the model. This suggests that there is long-run relationship between Nigerian oil and gas exports on one hand, and at least one of the independent variables, namely oil price, developed NEICs renewable energy consumption and GDP per capita, on the other hand.

\subsection{Other diagnostics tests}

The diagnostic tests results, presented in Table 7, have shown that the model is structurally and statistically sound. The serial correlation LM test suggests that there is no serial correlation in the residuals. Secondly, the Breuch-Godfrey test indicates that there is no sign of heteroscedasticity in the error terms. Thirdly, the RESET test indicates that the model is correctly specified.

Table 7 Diagnostic tests

\begin{tabular}{|c|c|c|c|c|}
\hline \multirow[t]{2}{*}{ Test type } & \multicolumn{2}{|c|}{ LM Version } & \multicolumn{2}{|c|}{ F Version } \\
\hline & Chi-square & P-value & F-stat. & P-value \\
\hline A:Serial Correlation & 1.079 & 0.299 & 0.838 & 0.369 \\
\hline B:Functional Form & 0.357 & 0.550 & 0.271 & 0.607 \\
\hline C:Normality & 2.033 & 0.362 & \multicolumn{2}{|c|}{ Not applicable } \\
\hline D:Heteroscedasticity & 0.127 & 0.722 & 0.119 & 0.732 \\
\hline $\begin{array}{l}\text { A:Lagrange multiplie } \\
\text { B:Ramsey's RESET te } \\
\text { C:Based on a test of } \\
\text { D:Based on the regre }\end{array}$ & $\begin{array}{l}\text { correlation; } \\
\text { the fitted valu } \\
\text { of residuals; } \\
\text { uals on square }\end{array}$ & s; & & \\
\hline
\end{tabular}

Fourthly, the plots of the cumulative sum of recursive residuals (CUSUM) and the cumulative sum squares of recursive residuals (CUSUMQ), which test structural stability, depict that the estimated parameters are stable over the sample period of the study (see, Figure 1 and 2). Lastly, the base line model results show an adjusted $\mathrm{R}^{2}$ of $64 \%$ (see, Table 5 ), which means our model explains about $64 \%$ of the variability of the selected independent variables in explaining the dependent variable. 
Figure 1 Plots of cumulative sum of recursive residuals

\section{Plot of Cumulative Sum of Recursive Residuals}

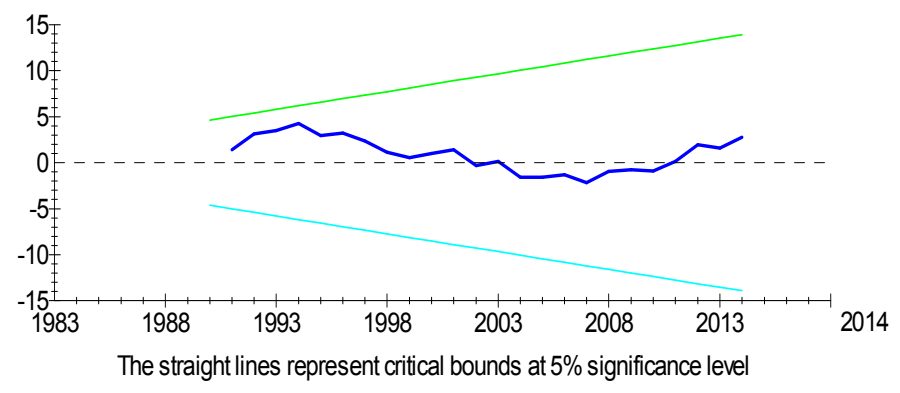

Figure 2 Plots of cumulative sum of squares of recursive residuals

\section{Plot of Cumulative Sum of Squares} of Recursive Residuals

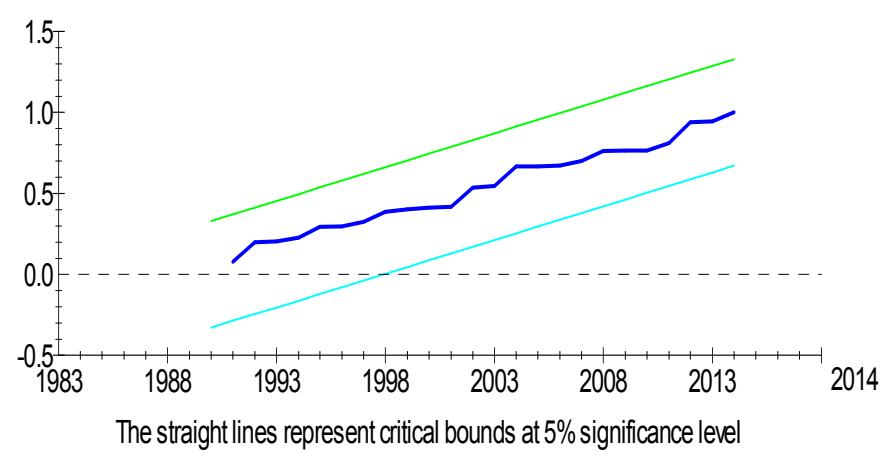

From the foregoing, the model seems correctly specified in terms of the selected variables and functionality. Hence, it is concluded that the results are consistent and the model is robust for policy formulation. The short-run and long-run empirical results of the model are presented in the next section.

\subsection{Short and long-run empirical results}

After establishing the existence of long-run cointegrating relationship between NOE and the three independent variables in the model through bounds test, the empirical results of the estimated short-run and long-run coefficients are presented in Table 8 and 9 as below. 
Table 8 Estimated short run dynamics and the error correction term

\begin{tabular}{lrr}
\hline $\begin{array}{l}\text { Dependent: } \Delta \ln (N O E) \\
\text { Regressor }\end{array}$ & Coefficient & Probability \\
\hline$\Delta \ln (N O E)(-1)$ & $0.359 * *$ & 0.016 \\
$\Delta \ln (G D P D E)$ & $-1.894 *$ & 0.065 \\
$\Delta \ln (O P D)$ & 0.011 & 0.891 \\
$\Delta \ln (R E D E)$ & $-0.256 * *$ & 0.018 \\
$\Delta \ln (R E D E)(-1)$ & $-1.555^{* *}$ & 0.026 \\
$E C M(-1)$ & $-0.641 * * *$ & 0.000 \\
$C$ & $23.537 *$ & 0.072 \\
\hline R-Squared & $71 \%$ & \\
R-Squared adjusted & $64 \%$ & \\
Observation (1983-2014) & 33 & \\
\hline
\end{tabular}

$* * *, * *$ and $*$ denote statistical significant, i.e. rejection of the null hypothesis at $1 \%, 5 \%$ and $10 \%$ levels of significance respectively

The results in Table 8 show the dynamic short-run relationships between $\Delta I n(N O E)$ and the three independent variables in the model. The ecm $(-1)$ coefficient is negative and statistically significant at $1 \%$, indicating that $64 \%$ of all deviations from the long-run equilibrium are adjusted in one year. Moreover, the short-run coefficients reveal a statistically significant negative relationships between Nigerian oil and gas exports to developed NEICs ( $\triangle I n N O E$ ) and such explanatory variables as renewable energy consumption ( $\triangle \operatorname{InREDE)}$ and GDP per capita $(\triangle / n G D P D E)$ of developed NEICs. Consequently, it is clear that in the short-run all the independent variables, except oil price, are significantly negatively associated with Nigerian oil and gas exports.

From the foregoing, GDP per capita of developed NEICs has a negative relationship with the dependent variable (NOEs) and is statistically significant at $10 \%$. Other factors held constant, a rise in GDP per capita of developed NEICs by $\$ 1$ causes 1.89 barrel decrease in NOEs demand in logarithmic terms. Although, not statistically significant, the coefficient of oil price shows a positive relationship with NOEs. More importantly, the coefficient of renewable energy consumption in developed NEICs shows a negative sign and is statistically significant at $5 \%$. This shows that an increase in renewable energy consumption by 1 unit in developed NEICs will lead to a 0.26 barrel decrease in Nigerian oil and gas export, other factors held constant. 
Table 9 Estimated long-run coefficients

\begin{tabular}{lrr}
\hline Dependent variable & InNOE & \\
Regressor & Coefficient & Probability \\
\hline InGDPDE & $-3.956^{* *}$ & 0.034 \\
InOPD & 0.0165 & 0.681 \\
InREDE & $-1.416^{* * *}$ & 0.002 \\
$C$ & $42.618^{* *}$ & 0.031 \\
\hline
\end{tabular}

$* * *, * *$ and $*$ denote statistical significant, i.e. rejection of the null hypothesis at $1 \%, 5 \%$ and $10 \%$ levels of significance respectively.

However, Table 9 presents the long-run results, which show that, consistent with the short-run model, presented in Table 8, both InGDPDE and InREDE have significant negative relationship with InNOE. Again, similar to the short-run model, InOPD is not significantly associated with Nigeria's oil and gas exports. Thus, renewable energy consumption and GDP per capita of developed NEICs are statistically significant at $1 \%$ and $5 \%$ alpha level respectively. GDP per capita in developed NEICs has a negative coefficient (-3.956) statistically significant at $5 \%$ alpha level. Holding other factors constant, this indicates that an increase in GDP in developed NEICs by 1 unit will lead to a decrease in Nigeria's NOEs by 3.96 barrels in logarithmic terms. Similarly, renewable energy consumption (InREDE) is significantly negatively associated with InNOE. This indicates that for every additional unit of renewable energy consumed in developed NEICs, there is a decrease in Nigerian export by 1.416 units. In line with the short-run results, the conclusion from the long-run results is that increases in the consumption of renewable energy in developed NEICs lead to the tendencies of these countries to lower their demand for Nigerian oil and gas.

\section{Discussion of results}

In pursuit of sustainable development, energy security, tackling global warming and avoiding the adverse impact of oil price volatility on their economies, advanced NEICs are evidently designing and putting in place strategic policies to enhance the generation and consumption of renewable energy. The obvious target, though definitely long-term in nature, is to stop relying on conventional energy sources mainly imported from NEECs. In this study, we tested whether transitioning to renewable energy consumption in advanced NEICs is having any significant effect on the oil and gas exports of an African NEEC, Nigeria. Consistent with the propositions of dependency theory, our results reveal that 
Nigeria's heavy dependence on the exports of oil and gas to advanced NEICs is exposing its economy to imminent risks of decreased foreign income in both the short-run and the long-run. This is indeed affecting the wellbeing of the country's economy. To position this finding within the context of dependency theory, we contend that Nigeria as a net energy exporter that relies substantially on developed NEICs for oil and gas exports is being adversely affected. On the other hand, the developed NEICs, on whose consumption of oil and gas Nigeria depends in generating export revenue, are pursuing policies aimed at reducing their oil and gas import volumes. While this will result in achieving macro environmental and carbon accountability goals by the NEICs, perhaps Nigeria is bound to lose significant share of oil and gas exports volume. This has the implication of reducing Nigeria's total revenue and budget financing. Many have attributed the recent economic hardship in the country to the significant decline in oil and gas exports revenue that we believe is partly being caused by energy transition. Unfortunately, the mono product status of the Nigerian economy is certainly making matters worse. Although the Nigerian economy has potentials for diversification due to abundance of many other resources in the country, persistent reliance on oil and gas in generating export revenue is impeding the much-needed diversification.

Our results further highlight that strategies to transition to cleaner sources of energy is working. This is indeed good news for the world, especially more so to the 164 nations (International Renewable Energy Agency, 2016) and such international organisation as World Bank, International Energy Agency, United Nations and OECD who have declared their unequivocal commitments and supports to renewable energy generation and consumption. Similarly, the significant negative relationship between GDP per capita and Nigeria's exports of oil and gas indicates likely economic prosperity for the NEICs facilitated by increased consumption of energy from renewable sources. This finding is consistent with the results showing significant positive association between GDP and renewable energy consumption (see, for example, Apergis and Payne, 2010a, 2010b; Apergis and Payne, 2011; Narayan and Smyth, 2008; Tugcu et al., 2012; Bhattacharya, 2016).

As previously stated, obviously our results imply good news for the world. This is especially true when the results are examined from the viewpoint of 
sustainability and better quality of life on this planet. Conversely, however, the results convey bad news to Nigeria and other similar NEECs who rely heavily on oil and gas as their major sources of export revenues. Thus, both the short-run and the long-run negative effects of renewable energy consumption in advanced NEICs on the oil and gas exports of Nigeria denote that revenue generations from the exports of crude oil and natural gas will very much likely continue to dwindle in both the immediate and the distant future. Apparently, this is a signal for the country to diversify the economy and develop other alternative sources of export revenue. This hint does not only apply to Nigeria, but it also represents an indication for other similar NEECs, who rely significantly on oil and gas exports, to seek other sources of revenue. Moreover, our results indicate that hydrocarbons as sources of energy are slowly becoming obsolete and irrelevant. In this regard, on 12th December 2017, the World Bank announced its plan to end financing of oil and gas exploration and development projects effective from 2019 (The Telegraph, 2017).

\section{Conclusions and policy implications}

This paper has examined, through the lens dependency theory, the effect of renewable energy consumption by NEICs on the Nigeria's oil and gas exports demand. The study has used ARDL bounds testing approach to cointegration to achieve its objective. Time-series data was collected, organised and subjected to the formalities of the ARDL. Our results show that, in both short and long run, consumption of energy from renewable sources in developed NEICs and their GDP per capita are significantly negatively associated with Nigeria's oil and gas exports. On the bright side, the results of our study show that the efforts being made by various advanced countries, NGOs and other influential organisations to achieve sustainable development is yielding positive results. This is because as consumption of energy from renewable sources in developed NEEC is increasing, oil and gas exports of a country that relies heavily on hydrocarbons is decreasing. This is indeed happening now, so reveal our results, and will continue to happen in the distant future. However, from Nigeria's viewpoint, our results spell economic doom for her. As such, we conclude that the on-going transition to renewable energy is rendering hydrocarbons, as sources of energy, obsolete and irrelevant. Consequently, Nigeria and other similar NEICs will likely 
have no option but to discard the exploitation of oil and gas resources and seek other more sustainable sources of export revenues.

Based on our discussion of results in section 4 and the conclusion in this section highlighting our major findings, we summarise policy implications of this study as follows. Firstly, in the short-run, there is an urgent need for Nigeria to focus on developing internal market trajectories to increase domestic utilisation of its conventional energy rather than depending on external markets for the sale of the nation's energy resources. Secondly, in the long-run, there is the need for public policy and decision makers to generate sustainability policies, develop a practical strategic plan and earnestly implement these policies and plans to effectively deal with the external economic threats arising from the influence of global energy transition. Thirdly, our results constitute evidence that implementations of renewable energy policies in developed NEICs are working. A fourth policy implication of our study relates to how innovation in developed NEICs, in the form of production of energy from renewable sources using contemporary technology, is worsening the economic condition of a third-world NEEC and making those of NEICs better (So, 1990; Valenzuela and Valenzuela, 1978). Based on the proposition of dependency theory, Nigeria as a less developed NEEC was content to rely on the exports revenue derived from the sales of hydrocarbons to advanced NEICs. Policy makers in the country do not appear to take seriously the possibility that innovations through technological advancements may change the game away from Nigeria's favour. Unfortunately, Nigeria does not possess the technical expertise to compete with advanced countries in counteracting the unfavourable changes in its interdependent relationships with the major buyers of its oil and gas resources. In addition, commercial discoveries of other similar sources of energy, like shale oil and gas, might have put Nigeria in a more disadvantaged position in this unbalanced interdependent relationship.

We encounter three outstanding limitations in conducting this research. Firstly, in terms of its temporal property, our sample is rather small as the time period covered is 35 years (1980-2014). Analysing time-series data using the standard vector autoregressive modelling, through for example, Johansen cointegration, is quite challenging. Following many previous studies, we addressed this limitation by using ${ }_{20} \mathrm{RD}$. Secondly, a higher frequency data-set would have been 
preferred, had data on all variables been available. In particular, monthly or quarterly data for the Nigerian oil and gas exports (NOE) and the renewable energy consumption (REDE) in NEICs are not available for more than half the time period covered. Again, ARDL has been very impressive in producing consistent and efficient results for annual time-series dataset. Finally, as our study considers only one NEEC (Nigeria), there is the need for future studies to conduct similar research taking a different NEEC and major importers of its oil and gas to further verify our findings. Alternatively, future research may consider conducting similar study by looking at more than one NEEC. 


\section{References}

Agbaeze, E.K., Udeh, S.N. and Onwuka, I.O., (2015), "Resolving Nigeria's dependency on oil: The derivation model", Journal of African Studies and Development, Vol. 7, No. 1, p.1.

Agbebi, M., and Virtanen, P. (2017), January), "Dependency TheoryA Conceptual Lens to Understand Chbbkina's Presence iwrn Africa?", Forum for Development Studies, Routledge, pp. 1-23.

Ahiakpor, J. C. (1985), "The success and failure of dependency theory: The experience of Ghana", International Organization, Vol. 39, No. 3, pp. 535 $-552$.

Akella, A.K., Saini, R.P. and Sharma, M.P., (2009), "Social, economical and environmental impacts of renewable energy systems", Renewable Energy, Vol. 34, No. 2, pp.390-396.

Aliyu, M.A., (2005), "Foreign direct investment and the environment: Pollution haven hypothesis revisited", In Eight Annual Conference on Global Economic Analysis, Lübeck, Germany, pp. 9-11.

Apergis, N., and Payne, J. E. (2010b), "Renewable enerqy consumption and growth in Eurasia", Energy Economics, Vol. 32, No. 6, pp. 1392-1397.

Apergis, N., and Payne, J. E., (2010a), "Renewable energy consumption and economic growth: evidence from a panel of OECD countries", Energy policy, Vol. 38 , No. 1 , pp. 656-660.

Apergis, N., and Payne, J. E., (2011), "The renewable energy consumptiongrowth nexus in Central America", Applied Energy, Vol. 88, Vol. 1, pp. 343-347.

Balcilar, M., Kutan, A. M. and Yaya, M. E., (2017), "Testing the dependency theory on small island economies: The case of Cyprus", Economic Modelling, Vol. 61 , pp. 1-11.

Banerjee, A., Dolado, J. and Mestre, R., (1998), "Error-correction mechanism tests for cointegration in a single-equation framework", Journal of time series analysis, Vol. 19, No. 3, pp. 267-283.

Belal, A.R., Cooper, S.M. and Roberts, R.W., (2013), "Vulnerable and exploitable: The need for organisational accountability and transparency in emerging and less developed economies", Accounting Forum, Vol. 37, No. 2, pp. 81-91).

Bhattacharya, M., Paramati, S. R., Ozturk, I. and Bhattacharya, S., (2016), "The effect of renewable energy consumption on economic growth: Evidence from top 38 countries", Applied Energy, Vol. 162, pp. 733-741.

Central Bank of Nigeria, (2015), "Annual statistical bulletin: Public finance statistics", published 7/31/2015. [online]. Available from: https://www.cbn.gov.ng/documents/Statbulletin.asp [Accessed 20/06/2016]. 
Central Bank of Nigeria., (2014), "External Trade Statistics: Average Crude Oil price (US \$)" [online]. Available from: http://statistics.cbn.gov.ng/cbnonlinestats/DataBrowser.aspx [Accessed 31/07/2015].

Dos Santos, T., (1970), "The structure of dependence", The American Economic Review, Vol. 60, No. 2, pp 67-79.

Duasa, J., (2007), "Determinants of Malaysian trade balance: An ARDL bound testing approach", Global Economic Review, Vol. 36, No. 1, pp.89-102.

Energy Information Administration, (2014), "International energy outlook 2014: World petroleum and other liquid fuels", [online]. Available from: https://www.eia.gov/forecasts/ieo/pdf/0484.pdf, [Accessed 22/12/2015].

Energy Information Administration, (2016), "International Energy Statistics: All Renewable Energy", [online]. Available from: http://www.eia.gov/cfapps/ipdbproject/iedindex3.cfm?tid=2\&pid=29\&aid=12\&ci

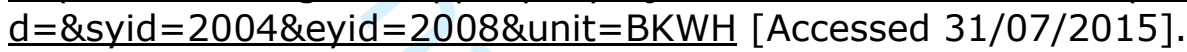

Engle, R. F., and Granger, C. W., (1987), "Co-integration and error correction: representation, estimation, and testing", Econometrica: Journal of the Econometric Society, Vol. 55, No. 2, pp. 251-276.

Ferraro, V. (2008), "Dependency theory: An introduction", The Development Economics Reader, Vol. 12, No. 2, pp. 58-64.

Foxon, T.J., Hammond, G.P. and Pearson, P.J., (2010), "Developing transition pathways for a low carbon electricity system in the UK", Technological Forecasting and Social Change, 77(8), pp.1203-1213.

Frank, A.G., (1972), "The development of underdevelopment". [online]. Available from: http://www.ou.edu/uschina/gries/articles/IntPol/GunderFrank.1972.pdf [Accessed 09/07/2014].

Frank, Andre and Gunder, (1966), "Development of underdevelopment", Monthly Review, Vol. 18, No. 4, pp. 17-21.

Fuinhas, J. A. and Marques, A. C., (2012), "Energy consumption and economic growth nexus in Portugal, Italy, Greece, Spain and Turkey: an ARDL bounds test approach (1965-2009)", Energy Economics, Vol. 34, No. 2, pp. 511 $-517$.

Hassan, A. and Kouhy, R., (2014), "Time-series cross-sectional environmental performance and disclosure relationship: specific evidence from a less-developed country", International Journal of Accounting and Economics Studies, Vol. 2, No. 2, pp. 60-73.

Hoogvelt, A., (1984), "The Third World in Global Development", London: Macmillan.

Intergovernmental Panel on Climate Change, (2014), "Climate Contribution of working group", the physical science basis. New York: Cambridge University Press. 
Internal Energy Agency, (2015), "Key World Energy Statistics, OECD, IEA, 2015", [online]. Available from: http://www.iea.org/publications/freepublications/publication/KeyWorld Statistics 2015.pdf [Accessed 22/12/2015].

Jalil, A. and Ma, Y., (2008), "Financial development and economic growth: time series evidence from Pakistan and China. Journal of Economic Cooperation", Vol. 29, No. 2, pp. 29-68.

Johansen, S., (1991), "Estimation and hypothesis testing of cointegrating vectors in the presence of a linear trend", Econometrica, Vol. 59, pp.1551-1580.

Johansson, D.J., Azar, C., Lindgren, K. and Persson, T.A., (2009), "OPEC strategies and oil rent in a climate conscious world", The Energy Journal, Vol. 30, No. 3, pp.23-50.

Jorgenson, A.K., (2012), "Energy: Analysing fossil-fuel displacement", Nature Climate Change, Vol. 2, No. 6, pp. 398-399.

Kremers, J. J., Ericsson, N. R. and Dolado, J. J., (1992), "The power of cointegration tests", Oxford bulletin of economics and statistics Vol. 54, No. 3, 325-348.

Lin, T.B. and Sung, Y.W., (1983), "Tourism in Asia: The economic impact OPEC strategies and oil rent in a climate conscious world", Pye, E.A. and Lin, T.B. Ed., Singapore: Singapore University Press: 50-62.

Marques, A. C. Fuinhas, J. A., and Menegaki, A. N. (2016), "Renewable vs nonrenewable electricity and the industrial production nexus: Evidence from an ARDL bounds test approach for Greece", Renewable Energy, Vol. 96, pp. 645655.

Menegaki, A. N., (2011), "Growth and renewable energy in Europe: A random effect model with evidence for neutrality hypothesis", Energy Economics, Vol. 33, No. 2, pp. 257-263.

Moriarty, P. and Honnery, D., (2012), "What is the global potential for renewable energy?", Renewable and Sustainable Energy Reviews, Vol. 16, No. 1, pp. 244252.

Murthy, V. N. and Okunade, A. A., (2016), "Determinants of US health expenditure: Evidence from autoregressive distributed lag (ARDL) approach to cointegration, Economic Modelling, Vol. 59, pp. 67-73.

Namkoong, Y., (1999), "Dependency theory: Concepts, classifications, and criticisms", International Area Review, Vol. 2, No. 1, pp. 121-150.

Narayan PK. (2002), "A tourism demand model for Fiji, 1970-2000", Pacific Economic Bulletin, Vol. 17, No. 2, pp. 103-116.

Narayan, P. K. (2004), "Fiji's tourism demand: the ARDL approach to cointegration", Tourism Economics, Vol 10, No. 2, pp. 193-206. 
Narayan, P. K., and Smyth, R., (2008), "Energy consumption and real GDP in G7 countries: new evidence from panel co-integration with structural breaks. Energy Economics, 30(5), 2331-2341.

Nigerian National Petroleum Corporation, (2014), "Annual Statistical Bulletin", [online]. Available from: http://www.nnpcgroup.com/PublicRelations/OilandGasStatistics/AnnualStatistics Bulletin.aspx [Accessed 31/07/2015].

Nigerian National Petroleum Corporation, (2015), "Annual Statistical Bulletin", [online]. Available from: http://nnpcgroup.com/Portals/0/Monthly\%20Performance/2015\%20ASB\%201st \%20edition.pdf [Accessed 01/11/2017].

Nosier, S.A.H., (2012), "Estimating the international tourism demand for Egypt: 'An econometric approach"' University of Hull.

Odhiambo, N. M., (2009), "Energy consumption and economic growth nexus in Tanzania: An ARDL bounds testing approach", Energy Policy, Vol. 37, No. 2, pp. 617-622.

Ozturk, I. and Acaravci, A., (2010), "The causal relationship between energy consumption and GDP in Albania, Bulgaria, Hungary and Romania: Evidence from ARDL bound testing approach", Applied Energy, Vol. 87, No. 6, pp. 1938-1943.

Ozturk, I. and Acaravci, A., (2011), "Electricity consumption and real GDP causality nexus: Evidence from ARDL bounds testing approach for 11 MENA countries", Applied Energy, Vol. 88, No. 8, pp. 2885-2892.

Payne, J. E., (2009), "On the dynamics of energy consumption and output in the US", Applied Energy, Vol. 86, No. 4, pp. 575-577.

Pesaran, B. and Pesaran, M.H., (2010), "Time Series econometrics using Microfit 5.0: A user's manual", New York. Oxford University Press, Inc.

Pesaran, M. H. and Shin, Y., (1998), "An autoregressive distributed -lag modelling approach to cointegration analysis", Econometric Society Monographs, Vol. 31, pp. 371-413.

Pesaran, M. H., and Shin, Y., (1998), "An autoregressive distributed -lag modelling approach to cointegration analysis", Econometric Society Monographs, Vol. 31, pp. 371-413.

Pesaran, M. H., Shin, Y., and Smith, R. J., (2001), "Bounds testing approaches to the analysis of level relationships", Journal of Applied Econometrics, Vol. 16, No. 3., pp. 289-326.

Pesaran, M.H., and Shin, Y., (1999), "An autoregressive distributed lag modelling approach to cointegration analysis", in Storm, S., ed., Econometrics and economic theory in the 20th century: The Ragnar Frisch Centennial Symposium, Cambridge University Press, Cambridge. 
Rahman, M. M. and Kashem, M. A., (2017), "Carbon emissions, energy consumption and industrial growth in Bangladesh: Empirical evidence from ARDL cointegration and Granger causality analysis", Energy Policy, Vol. 110, pp. 600608.

Rajagopal, D. and Zilberman, D., (2007), "Review of environmental, economic and policy aspects of biofuels", Economic and Policy Aspects of Biofuels World Bank Policy Research Working Paper, (4341).

Saayman, A. and Saayman, M., (2008), "Determinants of inbound tourism to South Africa", Tourism Economics, Vol. 14, No. 1, pp.81-96.

Saikkonen, P., (1991), "Asymptotically efficient estimation of cointegration regressions", Econometric theory, Vol . 7, No. 1, pp.1-21.

Sari, R., and Soytas, U., (2004), "Disaggregate energy consumption, employment and income in Turkey", Energy Economics, Vol. 26, No. 3, pp. 335344.

Shittu, O. I., Yemitan, R. A., \& Yaya, O. S. (2012). "On autoregressive distributed lag, cointegration and error correction model [An Application to Some Nigeria Macroeconomic Variables]". Australian Journal of Business and Management Research, 2(8), 56.

Smith, R.P., (2014), "Is renewable energy viable?", Petroleum Accounting and Financial Management Journal, Vol. 33, No. 3, pp 22.

So, A. Y. (1990). "Social change and development: Modernization", dependency and world-system theories, No. 178), Sage.

Soytas, U., and Sari, R. (2003). "Energy consumption and GDP: causality relationship in G-7 countries and emerging markets", Energy economics, Vol. 25, Vol.1, pp. 33-37.

Sun, C., Zhang, F. and Xu, M., (2017), "Investigation of pollution haven hypothesis for China: An ARDL approach with breakpoint unit root tests", Journal of Cleaner Production, In press.

Sunkel, O., (1969), "National development policy and external dependence in Latin America", The Journal of Development Studies, Vol. 6, No.1, pp. 23-48.

Szklo, A. and Schaeffer, R., (2006), "Alternative energy sources or integrated alternative energy systems? Oil as a modern lance of peleus for the energy transition", Energy, Vol. 31, No. 14, pp.2513-2522.

The Telegraph, (2017), "World Bank Group pledges to stop investing in oil and gas exploration", 12 December, 2017, 7:28 PM.

Tugcu, C.T., Ozturk, I. and Aslan, A., (2012), "Renewable and non-renewable energy consumption and economic growth relationship revisited: Evidence from G7 countries", Energy economics, Vol. 34, No. 6, pp. 1942-1950. 
Tursoy, T., and Faisal, F., (2017), "The impact of gold and crude oil prices on stock market in Turkey: Empirical evidences from ARDL bounds test and combined cointegration", Resources Policy, In press.

Umbach, F., (2010), "Global energy security and the implications for the EU", Energy Policy, Vol. 38, No. 3, pp. 1229-1240.

Valenzuela, J. S. and Valenzuela, A. (1978), "Modernization and dependency: Alternative perspectives in the study of Latin American underdevelopment", Comparative politics, Vol. 10, No. 4, pp. 535-557.

von Eije, H., von Eije, S. and Westerman, W., (2013), "Renewable energy production capacity and consumption, economic growth and global warming", In Energy Economics and Financial Markets (pp. 73-90). Springer Berlin Heidelberg.

Waziri, B.Z., (2016), "An empirical investigation of the impact of global energy transition on Nigerian oil and gas export", PhD thesis. University of Abertay, Dundee. UK.

World Bank., (2016), "World Development Indicators. UK Data Service", [online]. Available from: http://dx.doi.org/10.5257/wb/wdi/2016-06-15 [Accessed 14/10/2016].

Yamin, F., (1998), "The Kyoto Protocol: Origins, assessment and future challenges", Review of European Community \& International Environmental Law, Vol. 7, No. 2, pp. 113-127.

Yergin, D., (2006), "Ensuring energy security", Foreign Affairs, Vol. 85, No. 2, pp. 69-82.

Yergin, D., (2008), "The prize: The epic quest for oil, money and power", New York, USA: Free Press. 